\title{
Effect of prenatal and postnatal protein under nutrition on brain development in rat's pups
}

\section{Introduction}

Malnutrition is a worldwide problem affecting millions of infants and young children during the most vulnerable stages of their brain development. Neuro-pharmacological studies showed that malnutrition alters various maturational events and induces changes in the function of brain neural receptors resulting in behavioral abnormalities that alter cognitive functioning and disturbances in learning and memory. ${ }^{1}$ Malnutrition exerts its effects on brain development, not only during the so-called brain growth spurt period, but also during early organizational processes such as neurogenesis, cell migration and differentiation. ${ }^{2}$ Maturation of the nervous system especially the hypothalamus and the hippocampus and consequent behavior depends on prenatal nutrition status. ${ }^{3}$ Arborization and span of the basilar dendrites of large pyramidal cells for layer $\mathrm{V}$ in the motor cortex of infants was less in undernourished group than that of normally nourished group. These cellular changes were proposed to cause neuropsychological deficits that occur in those infants. ${ }^{4}$ In rat also, malnutrition affects dendritic branching of claustral neurons ${ }^{5}$ and induces central noradrenergic hyperactivity which exerts a tropic role during brain development, resulting in functional brain disturbances. ${ }^{6}$ In rats, prenatal protein under nutrition affected adversely the morphologic development of occipital cortex leading to an increase in neuronal cell packing density and a decrease in dendritic branching. ${ }^{7}$

\section{Protein under nutrition}

Nutrition is probably the single greatest environmental influence both on the fetus and neonate, and plays a necessary role in the maturation and functional development of the central nervous system. ${ }^{2,8}$ It has been recognized that protein under nutrition has significant adverse effects on cognitive development, school performance and emotional stability and behavior itself. ${ }^{9}$ Protein under nutrition is worldwide problem especially in the developing countries. Although the effects of protein under nutrition during pregnancy are reported to be less severe because of the protective role of the placenta, the timing of the intake of a protein-deficient diet seems to be important, producing different effects as indicated by a decreased body and brain weight and DNA content. ${ }^{8}$ Prenatal protein under nutrition adversely affects the developing brain in numerous ways, depending largely on its timing in relation to various developmental events in the brain and to a lesser extent on the type and severity of the deprivation. ${ }^{2}$ Prenatal protein under nutrition resulted in slower head growth in utero as measured by ultrasound, ${ }^{10}$ low birth weight, ${ }^{11}$ small size for gestational age. ${ }^{12}$ Niestroj ${ }^{13}$ noted that positive relations between anthropometric indices of mild prenatal protein under nutrition and subsequent performance. Numerous studies reported that cognitive impairment resulted from prenatal and early postnatal malnutrition., ${ }^{2,14,15}$

\section{Effects of protein under nutrition on rat}

The study of animals is essential for estimation of the potentially harmful effects of under nutrition on humans. The rat is the most frequently used experimental model of under nutrition. Both prenatal and postnatal protein under nutrition affect brain development. In prenatal period the organization of specific neurons during

\author{
Volume I Issue 5 - 2015
}

Ghada Abdel-Hamid A

Department of Anatomy, King Abdulaziz University, Saudi Arabia

Correspondence: Ghada Abdel-Hamid A, Department of Anatomy, King Abdulaziz University, Saudi Arabia, Emailgmohamed@kau.edu.sa, ghadal69@hotmail.com

Received: December 12, 2015 | Published: December 16, 2015

ontogenesis taken place, whereas in postnatal period the most rapid brain growth occurred. ${ }^{2}$ Katz and Davies ${ }^{16}$ found that postnatal protein under nutrition resulted in low body weight and brain weight among pups when compared to control ones. Granados-Rojas et al. ${ }^{3}$ reported that prenatal and postnatal undernourished rats had less body weight, less brain weight than well nourished rats. Diaz-Cintra et al ${ }^{17}$ found that the effect of the low protein diet is greater in layer $\mathrm{V}$ than layer II/III pyramidal neurons. Cintra et $\mathrm{al}^{3}{ }^{3}$ reported prenatal protein under nutrition altered the phase wake and rapid eye movements rhythms and the amplitude of slow wave sleep was decreased. The temporal structure of the undernourished rats may not allow proper synchronization of some sleep parameters. Escobar and Salas ${ }^{5}$ reported that in rat, both prenatal and postnatal under nutrition decreased width of dendrites and reduced complexity of dendritic branching and reduced the basal dendritic Arborization in large pyramidal cells of the Vth cortical layer. In human, the structure of large pyramidal cells from layer $\mathrm{V}$ of the motor cortex of undernourished and well-nourished infants was studied to determine the effects of postnatal nutrition on cortical dendritic development. In undernourished infants, the Arborization and span of the basilar dendrites were decreased in comparison to controls. These findings indicated that under nutrition experienced during the first months of postnatal life could affect the growth of pyramidal cells, especially the formation of basilar dendrites. ${ }^{4}$ SotoMoyano et al. ${ }^{6}$ reported that developmental protein under nutrition induced central noradrenergic hyperactivity; noradrenalin exerts a tropic role during brain development. Also, Soto-Moyano et al. ${ }^{7}$ found prenatal protein under nutrition in rat pups resulted in higher cortical percent of noradrenalin release than control pups. Exposure of pregnant rats to protein under nutrition throughout pregnancy alters the developing hippocampus, leading to increased inhibition and selective changes in hippocampal-mediated behaviors. ${ }^{18}$

\section{Conclusion}

Studies in rat, revealed that combined effect of prenatal and postnatal protein malnutrition reduced the brain weight, the thickness of the cerebral cortex, increase neuronal cell packing density and decreased dendritic branching.

\section{Acknowledgements}

None. 


\section{Conflict of interest}

Author declares that there is no conflict of interest.

\section{References}

1. Galler JR, Shumsky JS, Morgane PJ. Malnutrition and brain development In: Walker WA, Watkins JB, editors. Nutrition and pediatrics: basic science and clinical applications. Neuilly-Sure-Seine, Decker Europe, France; 1996. p. 194-210.

2. Morgane PJ, Austin-LaFrance R, Bronzino J, et al. Prenatal malnutrition and development of the brain. Neurosci Biobehav Rev. 1993;17(1):91-128.

3. Granados-Rojas L, Larriva-Sahd J, Cintra L, et al. Prenatal protein malnutrition decreases mossy fibers-CA3 thorny excrescences asymmetrical synapses in adult rats. Brain Res. 2002;933(2):164-171.

4. Cordero ME, D'Acuna E, Benvensite S, et al. Dendritic development in neocortex of infants with early postnatal life undernutrition. Pediatr Neurol. 1993;9(6):457-464.

5. Escobar C, Salas M. Dendritic branching of claustral neurons in neonatally undernourished rats. Biol Neonate. 1995;68(1):47-54.

6. Soto-Moyano R, Valladares L, Sierralta W, et al. Cerebral cortex: function and development. Neuron. 1995;15:497-505.

7. Soto-Moyano R, Alarcon S, Hernandez A, et al. Prenatal malnutritioninduced functional alterations in callosal connections and in interhemispheric asymmetry are prevented in the rat by reduction of noradrenaline synthesis during gestation. JNutr. 1998;128(7):1224-1231.

8. McDonald MA, Sigman M, Espinosa MP, et al. Impact of a temporary food shortage on children and their mothers. Child Dev. 1994;65(2):404-415.
9. Wachs TD. Relation of mild-to-moderate malnutrition to human development: Correlational studies. J Nutr. 1995;125(8):2245S-2254S.

10. Harvey D, Prince J, Button J, et al. Ability of children who were small for gestational age babies. Pediatrics. 1982;69(3):296-300.

11. Kirksey A, Rahmanifar A, Wachs TD, et al. Determinants of pregnancy outcome and newborn behavior of a semirural Egyptian population. Am J Clin Nutr. 1991;54(4):657-667.

12. Xu SX. Follow-up on physical and mental development in small-forgestational-age-infants. Zhonghua Fu Chan Ke Za Zhi. 1993;28(2):70-72.

13. Niestroj B. Fetal nutrition: a study of its effect on behavior in Zulu newborns. In: Nugent J, editor. The Cultural Context of Infancy. Ablex, Norwood, USA; 1991. p. 321-352.

14. Morgane PJ, Austin-LaFrance R, Bronzino J, et al. Malnutrition and the developing central nervous system. In: Isaacson RL, Jensen KF, editors. The vulnerable brain: nutrition and toxins. New York: Plenum Publishing Corporation, 1992. p. 3-44.

15. Morgane PJ, Mokler DJ, Galler JR. Effects of prenatal protein malnutrition on hippocampal formation. Neurosci Biobehav Rev. 2002;26(4):471-483.

16. Katz HB, Davis CA. The separate and combined effects of early undernutrition and environmental complexity at different ages on cerebral measures in rats. Dev Psychobiol. 1983;16(1):47-58.

17. Diaz-Cintra S, Cintra L, Ortega A, et al. Effects of protein deprivation on pyramidal cells of the visual cortex in rats of three age groups. $J$ Comp Neurol. 1990;292(1):117-126.

18. Luebke L, John J, Galler JR. Prenatal protein malnutrition results in increased frequency of miniature inhibitory synaptic currents in rat CA1 pyramidal cells. Synapse. 2000;37(1):23-31. 